\section{The responsibility of science and scientists}

Occasionally one unexpectedly comes across things that one has archived, thereby putting them out of mind, but which are useful when brought back into sight. In this fashion I just happened to come across the book "Transdisciplinarity: Joint Problem-Solving among Science, Technology, and Society" [1], which is, in effect, (part of) the proceedings of the eponymous conference held at the ETH in Zurich in the year 2000, a well attended conference in which I along with many others had enthusiastically participated. What remains of that enthusiasm today, I wonder? Transdisciplinarity was then considered to be the new concept that would enable, or at least help, humanity to solve its grand challenges such as climate change, demographic change and environmental pollution. But, as I read at the beginning of Richard Ernst's lecture at that conference [2], "I do not want to repeat how indispensable interdisciplinary or transdisciplinary research is for solving urgent problems. This was evident well before meetings with this subject were organized. But, so far, transdisciplinarity has remained a catchword and still awaits proper implementation." How very true. I can confirm that with especial intensity since I myself have been engaged in interdisciplinary and transdisciplinary research from my undergraduate days onwards. Reading that remark reminded me that Richard Ernst's contribution to the conference, on "The responsibility of science and scientists", was by far the most memorable one, with its insistence on uncompromising honesty ("without unlimited honesty, science loses its right of existence and can no longer provide a solid foundation for society"), hence I was interested to reread it in full.

His message, or messages, for he made several weighty points, are still very pertinent today. The one I want to focus on here is the idea of science working towards "a renewed foundation for a global society". This message has been given by others, including in the pages of this Journal [3, 4], but it still comes across very powerfully. Why, then, does it "still await proper implementation"?

Perhaps a clue is given in the lecture that immediately followed that of Ernst—Uwe Scheidewind's "Mobilizing the intellectual capital of universities", which I recall not because of its content (of which it was practically devoid) but because of its colourful, and at the same time primitive, "Powerpoint" slides, the animation of which somehow emphasized the lack of substance. Depressingly, a wise and very respected journalist of my acquaintance remarked to me in the break after those lectures that, unfortunately, it would be the message of Scheidewind, not that of Ernst, that would have the ear of the federal authorities in Berne. Reading it now I see that Scheidewind was beating the drum for "Mode 2 knowledge production" [5, 6], championed by Michael Gibbons, sometime Secretary General of the Association of Commonwealth Universities, who also spoke at the conference. In corroboration of the journalist's remark, the then Secretary of State for Science in Berne, Charles Kleiber, delivered a keynote address in which he called this the "ménage à trois" (of democracy, science, and the market economy) [7], essentially corresponding to the "triple helix" (of government, universities and firms) $[8,9]$. A decade later, the hubris has faded away and been replaced by warnings of the terrible corrupting dangers of commercializing universities and bending them to government behest [10] (warnings which themselves had been given, in essentially the same form, a century earlier [11]). ${ }^{1}$

Alas, "a threefold cord is not quickly broken", ${ }^{2}$ and this erroneously assembled one is proving to be no exception. Indeed, it still forms a pillar of government policy in the UK [13]. ${ }^{3}$ As a result, much effort is now going into fighting rearguard actions. ${ }^{4}$

One of the difficulties faced by opponents of the triple helix is that some of its tenets are attractive to the lay public who may, therefore, support it (note the emphasis on democracy in the ménage à trois). Surely, the layman will say, it is better to apply social, political and economic criteria to proposals for scientific research, formulated by lay people, who are, after all, the ultimate end users, rather than purely academic criteria formulated by university peers [5]. Will this not ensure the prompt and effective application of research effort to humanity's grand challenges?

\footnotetext{
1 Kleiber retired in 2007, exemplifying Buckle's remark that “... statesman, and legislators are more likely to retard than to hasten [the intellectual development of every civilized country ... they] are only to be regarded as the puppets who strut and fret their hour upon a little stage; while, beyond them, and on every side of them, are forming opinions and principles which they can scarcely perceive, but by which alone the whole course of human affairs is ultimately governed" [12]. On 23 May 2000, Robert M. Berdahl (Chancellor of the University of California, Berkeley) gave a speech at Erfurt University entitled "The Privatization of Public Universities", which also called attention to the great dangers of allowing the university-industrial complex to grow.

2 Eccl. 4, 12.

3. This policy appears to have been largely influenced by the document "Ingenious Britain. Making the UK the leading high tech exporter in Europe. A report by James Dyson" (March 2010), which strongly endorsed the notion of the "triple helix".

4 For example, the Council for the Defence of British Universities (CDBU), founded in November 2012.
} 
The answer to this question is, "unfortunately not". Above all, scientists need freedom to think in order to do effective work [14]. The sort of constraints explicit or implicit in the policy expounded by supporters of the triple helix $[13]^{3}$ kills creativity. The kinds of solutions needed for the grand challenges are very unlikely to emerge from any kind of programmed research. The corollary is that, going back to Richard Ernst, scientists must, without exception, adhere to a code of uncompromising integrity ("the most important virtue or value in science is honesty and self-criticism" [2]). Without that, science becomes discredited and, unsurprisingly, it becomes difficult for the lay public to trust scientists to act responsibly for the overall best interests of humanity, without attempting to control what they do. Some pessimists may take the view that the misdeeds of the past few decades have already irreversibly discredited scientists (and, a fortiori, science). A more robust view is to acknowledge the occurrence of scientific delinquency but firmly distance oneself from it and do all one can to diminish it and its effects. Upholding integrity in this way is not helped by the shameless rapacity of many contemporary scientists to grab as much funding for their work as possible, rather like the Adullamites in Francis Cornford's Microcosmographia Academica, ${ }^{5}$ both from government and industry. ${ }^{6}$ Both sources are fraught with dangerous temptations to abandon honesty and self-criticism if upholding them could lead to a diminution of income. Perhaps the "scientists" who choose to follow that path naïvely believe that their misdeeds will go undetected, either because at least some of their peers are doing the same or because the lay public will not be able to discern the difference between the results of honest and dishonest work. In this belief they are, however, grievously mistaken, not least because, beyond the reach of any human agent, there is a stern arbiter, nature, who, as Feynman has pointed out, "cannot be fooled" [18].

\section{J.J. RAMSDEN}

\section{References}

1. Thompson Klein, J., Grossbacher-Mansuy, W., Häberli, R., Bill, A, Scholz, R.W. and Welti, M. Transdisciplinarity:
Joint Problem-Solving among Science, Technology, and Society. An Effective Way for Managing Complexity. Basel: Birkhäuser (2001).

2. Ernst, R. The responsibility of science and scientists. In: [1], pp. 81-93.

3. Maxwell, N. Do we need a scientific revolution? J. Biol. Phys. Chem. 8 (2008) 95-105.

4. Hunt, G. The Lambda Limit: the incompletability of science. J. Biol. Phys. Chem. 12 (2012) 121-128.

5. Albert, M. and Bernard, P. Faire utile ou faire savant? Sociologie et Sociétés 32 (1999) 71-92.

6. Lesemann, F. La société des savoirs et la gouvernance: la transformation des conditions de production de la recherche universitaire. Lien Sociale et Politiques-RIAC 50 (autumn 2003) 17-37.

7. Kleiber, C. What kind of science does our world need today and tomorrow? A new contract between science and society. In: [1], pp. 47-58.

8. Etzkowitz, H. and Leydesdorff, L. The dynamics of innovation: from National Systems and "Mode 2" to a Triple Helix of university-industry-government relations. Research Policy 29 (2000) 109-123.

9. Shinn, T. The triple helix and new production of knowledge: prepackaged thinking on science and technology. Social Studies of Science 32 (2002) 599-614.

10. Ramsden, J.J. Integrity, administration and reliable research. Oxford Magazine No 323 (Noughth Week, Trinity Term, 2012), pp. 6-8.

11. Oliver, F.S. Ordeal by Battle, p. 129, pp. 183-184. London: Macmillan (1915).

12. Buckle, H.T. History of Civilization in England, vol. 1, p. 279. New York: D. Appleton \& Co. (1864).

13. Following Up the Wilson Review of Business-University Collaboration. Next Steps for Universities, Business and Government. London: Department for Business, Innovation and Skills (2012).

14. Thomson, G.P. The Strategy of Research (4th Fawley Foundation Lecture). University of Southampton (1957).

15. Harper, T. Global Funding of Nanotechnologies \& Its Impact. London: Cientifica (2011).

16. Haverkamp, R.G. Cheminanotechnology: nanotechnology for chemistry and chemical engineering. Chemistry in New Zealand, December 2005, pp. 10-11.

17. Drexler, K.E. Nanotechnology: from Feynman to funding. Bull. Sci. Technol. Soc. 24 (2004) 21-27.

18. Report of the Presidential Commission on the Space Shuttle Challenger Accident (Rogers Commission), Appendix F (6 June 1986).

\footnotetext{
5 Cambridge: Bowes \& Bowes (1908).

${ }^{6}$ It has been said that nanotechnology, which is (or has been) the recipient of vast government spending (e.g., [15]), is derived from the Greek word "nano" meaning "funding" [16]. See also [17].
} 